\title{
Serum-Red Cell Interactions at Low Ionic Strength: Erythrocyte Complement Coating and Hemolysis of Paroxysmal Nocturnal Hemoglobinuria Cells*
}

\author{
David E. Jenkins, Jr., $\nmid$ Robert C. Hartmann, and Albert L. Kerns \\ (From the Division of Hematology, Department of Medicine, Vanderbilt University School of \\ Medicine and the Veterans Administration Hospital, Nashville, Tenn.)
}

Summary. Complement coating and hemolysis were observed when erythrocytes from patients with paroxysmal nocturnal hemoglobinuria (PNH) were incubated in isotonic sucrose solution in the presence of small amounts of serum. Normal cells were likewise coated with complement components but did not hemolyze. Both normal and PNH erythrocytes reduced the hemolytic complement activity of the serum used in this reaction.

Experience with other simple saccharides and related compounds suggests that the low ionic strength of the sucrose solution is the feature that permitted complement coating of red cells and hemolysis of $\mathrm{PNH}$ erythrocytes. Isotonic solutions of other sugars or sugar alcohols that do not readily enter human erythrocytes could be substituted for sucrose.

The mechanism for these reactions may possibly relate to the agglutination observed with erythrocytes tested in the serum-sucrose system. Even though PNH hemolytic activity could be removed by prior heating of serum or barium sulfate treatment of plasma, the agglutination phenomenon still persisted.

The in vitro conditions necessary for optimal sucrose hemolysis of $\mathrm{PNH}$ erythrocytes were described and compared with those of the classical acid hemolysis test. The requirement for less serum in the sucrose hemolysis system than needed in the standard acid hemolysis reaction makes certain experiments, especially those using large amounts of autologous PNH serum, much more feasible. Additional advantages of the sucrose hemolysis test are that it can be carried out at room temperature in the presence of oxalate and citrate and that critical pH control is not essential. To date, the sucrose hemolysis test has been a sensitive and specific one for PNH. A modified test used for screening purposes, the "sugar water" test, is very easy to perform.

\section{Introduction}

Erythrocytes from patients with paroxysmal nocturnal hemoglobinuria hemolyze when incubated in isotonic sucrose solutions of low ionic strength in the presence of small amounts of

\footnotetext{
* Submitted for publication August 1, 1966; accepted January 12, 1967.

Supported in part by grants HE-03509, AM-10545, AM5129, and FR-95 from the U. S. Public Health Serivce.
}

serum (1). This observation has been used as the basis for a simple and specific diagnostic test for $\mathrm{PNH}$ recently reported from this laboratory (2). The term "sucrose hemolysis" has been chosen as a concisely descriptive one for this re-

†Clinical Investigator, Veterans Administration Hospital.

Address requests for reprints to Dr. David E. Jenkins, Jr., Veterans Administration Hospital, 1310 24th Ave. S., Nashville, Tenn. 37203. 
action although, as will be shown, sucrose per se does not directly hemolyze the PNH erythrocytes. The present report describes some of the variables affecting this reaction.

\section{Methods}

PNH erythrocytes and serum were obtained from eight patients currently under study in this laboratory. Patient numbers are the same as in previous publications $(3,4)$ with the more recent additions of Patients 9 and 10. Patients 1 and 6 are now deceased. Normal cells and serum were obtained from healthy young adult volunteers. Blood samples from patients with disorders other than $\mathrm{PNH}$ were obtained from the inpatient and outpatient services of Vanderbilt Hospital and the Nashville Veterans Administration Hospital. Serum and cells were separated by defibrination with glass beads under sterile conditions. When not used immediately, the cells were stored at $4^{\circ} \mathrm{C}$ in sterile modified Alsever's solution (5), and the serum was stored at $-70^{\circ} \mathrm{C}$. Before use the erythrocytes were washed thrice with normal saline.

Isotonic sucrose solution, as modified from the method of Harshman and Najjar (6), was prepared by dissolving $92.4 \mathrm{~g}(0.27 \mathrm{~mole})$ in $910 \mathrm{ml}$ of $5 \mathrm{mM} \mathrm{NaH}_{2} \mathrm{PO}_{4}$ and $90 \mathrm{ml}$ of $5 \mathrm{mM} \mathrm{Na} \mathrm{NPO}_{2}$. The $\mathrm{pH}$ was adjusted to 6.1 with $0.75 \mathrm{~N} \mathrm{NaOH}$ or $0.75 \mathrm{~N} \mathrm{HCl}$ if necessary. Isotonic solutions of glucose, mannose, raffinose, sorbitol, and mannitol were prepared by dissolving 0.27 mole of each in similar phosphate buffer solutions. Normal saline solution $(0.145 \mathrm{M})$ contained $8.5 \mathrm{~g} \mathrm{NaCl}$ per $\mathrm{L}$ of distilled water.

The standard sucrose hemolysis reaction mixture contained $0.85 \mathrm{ml}$ of sucrose solution ( $\mathrm{pH} 6.1$ unless otherwise stated), $0.05 \mathrm{ml}$ of unacidified autologous or isologous blood group compatible normal serum, and $0.1 \mathrm{ml}$ of a $50 \%$ saline suspension of erythrocytes. This provided a final concentration of $5 \%$ serum and $5 \%$ erythrocytes. Osmolalities when measured ranged between 299.0 and $308.5 \mathrm{mOsm}$ for sucrose solution, serum-sucrose mixture, and serum-sucrose-erythrocyte mixture. The standard incubation period was for 30 minutes at $37^{\circ} \mathrm{C}$.

Acid hemolysis and thrombin tests were carried out by previously described methods $(7,8)$. These reaction mixtures each contained $0.9 \mathrm{ml}$ of acidified serum $(\mathrm{pH}$ 6.2 to 6.5 ) and $0.1 \mathrm{ml}$ of a $50 \%$ saline suspension of erythracytes with the thrombin test containing in addition $50 \mathrm{U}$ of bovine thrombin. 1

After incubation at $37^{\circ} \mathrm{C}$ the tubes containing the above reaction mixtures were inverted several times and centrifuged, and the supernatants were removed for determination of per cent hemolysis. Unlysed cells (i.e., surviving hemolysis in these tests) were washed thrice with normal saline and subjected to antiglobulin agglutination tests that were read macroscopically on a glass tile as previously described (8).

1 Thrombin topical (bovine) was kindly supplied by the Upjohn Co., Kalamazoo, Mich.
Studies were designed to measure certain variables affecting the sucrose hemolysis reaction. Ionic strength was varied by stepwise replacement of sucrose with 0.145 $M$ saline while maintaining the serum and erythrocyte concentrations at $5 \%$ each in the reaction mixture. In ionic strength determinations all reactants except the erythrocytes were mixed, and the conductance was measured with a Radiometer conductivity meter. ${ }^{2}$ Conductance readings were converted to ionic strength values with saline standards. The per cent of serum in the reaction mixture was varied by adjusting the amounts of serum and sucrose employed while maintaining a $5 \%$ concentration of erythrocytes. It is recognized that this maneuver varies ionic strength as well as the percentage of serum in the reaction. In indicated experiments the $\mathrm{pH}$ of the serum-sucrose mixture was adjusted with $0.05 \mathrm{~N}$ $\mathrm{HCl}$ or $0.05 \mathrm{~N} \mathrm{NaOH}$ before the addition of erythrocytes.

The effect of certain anticoagulants on sucrose hemolysis was determined by mixing one part of anticoagulant with nine parts of serum before addition to the sucrose hemolysis reaction mixture. In some experiments when a very high concentration of anticoagulant to serum (e.g., $50 \mathrm{mM}$ ) in the reaction mixture was desired, the dry anticoagulant was dissolved in sucrose solution before the addition of the serum.

The role of thrombin in sucrose hemolysis was investigated. Commercial bovine thrombin was dissolved in serum or for higher concentrations in the sucrose solution before mixing these reactants. In other experiments oxalated plasma treated with $\mathrm{BaSO}_{4}{ }^{3}$ to remove prothrombin activity was used in place of serum in the reaction mixture. Nine parts of whole blood mixed with one part of $M / 10$ sodium oxalate served as the source of oxalated plasma. The $\mathrm{BaSO}_{4}$ was prepared as a water suspension containing $100 \mathrm{mg}$ per $\mathrm{ml}$. The desired amount of $\mathrm{BaSO}_{4}$ suspension was then pipetted into a tube and centrifuged. The aqueous supernatant was removed, and plasma was then added and mixed with the packed $\mathrm{BaSO}_{4}$. After 10 minutes' incubation at $37^{\circ}$ the $\mathrm{BaSO}_{4}$ was removed by centrifugation. A second centrifugation assured complete removal of the $\mathrm{BaSO}_{4}$ from the plasma.

Sera lacking complement components or properdin (R1, R2, R3, R4, and RP) were prepared by standard methods $(5,9)$, except that the final dilutions were made in $0.27 \mathrm{M}$ buffered sucrose solution rather than barbitalbuffered saline. The utilization of complement in the sucrose hemolysis system was tested in the following manner. Serum-sucrose mixtures were incubated for $30 \mathrm{~min}$ utes at either $4^{\circ}$ or $37^{\circ}$ in the absence of erythrocytes. Similar mixtures were also incubated at $37^{\circ}$ with normal as well as PNH erythrocytes. At the end of the incubation period all tubes were centrifuged for 3 minutes at room temperature in a Clay-Adams serofuge. The su-

\footnotetext{
2 London Co., Westlake, Ohio.

3 Barium sulfate, Mallinckrodt Chemical Works, St. Louis, Mo.
} 
pernatants were then removed, and hemolytic complement activity was determined by the method of Kabat and Mayer (5). The conductance of samples to be tested was adjusted to that of isotonic barbital-buffered saline (5) with five times concentrated buffer. Normal serum complement values for this laboratory are $33 \pm 11 \mathrm{C}^{\prime} \mathrm{H}_{50}$ $\mathrm{U}$ per $\mathrm{ml}$. The hemolytic unit of complement, $\mathrm{C}^{\prime} \mathrm{H}_{50}$, represents that amount of serum which will bring about the hemolysis of $2.5 \times 10^{8}$ of $5.0 \times 10^{8}$ optimally sensitized sheep red blood cells under appropriate conditions as defined by Kabat and Mayer (5).

Antisera to $\gamma \mathrm{G}$-globulin (anti- $\gamma \mathrm{G}$ ) and human complement (anti- $C^{\prime}$ ) were prepared as previously described (8). The anti- $\gamma \mathrm{G}$ serum agglutinated $\gamma$-globulin-coated erythrocytes but not complement-coated red cells. Immunoelectrophoresis (10) with whole serum resulted in a single $\gamma \mathrm{G}$-globulin precipitin band. The antiserum to human complement (anti- $\mathrm{C}^{\prime}$ ) agglutinated complement-coated erythrocytes but not $\boldsymbol{\gamma}$-globulin-coated cells. Immunoelectrophoresis of this antiserum with whole serum resulted in two $\beta$-globulin bands corresponding to the complement proteins $\beta_{1 \mathrm{C}}$-globulin (11) and $\beta_{1 \mathrm{E}}$-globulin (12) described by Müller-Eberhard and associates. ${ }^{4}$

Trypsinized normal erythrocytes, which are similar to $\mathrm{PNH}$ erythrocytes in their susceptibility to acid hemolysis, were prepared with Bacto-trypsin 5 according to the method of Yachnin, Laforet, and Gardner (13). Reactions employing $0.5 \mathrm{ml}$ of cold agglutinin serum, $0.4 \mathrm{ml}$ of normal serum, and $0.1 \mathrm{ml}$ of packed group $\mathrm{O}$ erythrocytes were incubated at $23^{\circ} \mathrm{C}$ for 2 hours. The mixture of cold agglutinin and normal serum was acidified to $\mathrm{pH} 6.5$ with $\mathrm{N} / 3 \mathrm{HCl}$ before addition of the erythrocytes.

\section{Results}

Sensitivity and specificity of the sucrose hemolysis test. Table I compares results obtained in simultaneously performed sucrose hemolysis, acid hemolysis, and thrombin tests with red cells from all eight $\mathrm{PNH}$ patients studied. Although autologous sera were used in this set of experiments, isologous blood group compatible sera gave similar results. Per cent hemolysis in the sucrose system was greater than that in the acid hemolysis test and frequently of the same order of magnitude as in the thrombin test. As with the acid hemolysis and thrombin tests, in the sucrose system normal cells did not hemolyze when incubated with PNH sera, confirming that the hemolytic susceptibility of $\mathrm{PNH}$ blood in this system as in other systems lies in the red cells.

The specificity of this reaction as a diagnostic

${ }^{4}$ Specific antisera to $\beta_{1 \mathrm{C}}$-globulin and $\beta_{1 \mathrm{E}}$-globulin were kindly provided by Dr. Müller-Eberhard.

5 Difco Labs., Detroit, Mich.
TABLE I

Sucrose hemolysis and other hemolytic tests in $P N H^{*}$

\begin{tabular}{cccc}
\hline \hline $\begin{array}{c}\text { PNH } \\
\text { patient } \\
\text { no. }\end{array}$ & $\begin{array}{c}\text { Sucrose } \\
\text { hemolysis } \\
\text { test }\end{array}$ & $\begin{array}{c}\text { Acid } \\
\text { hemolysis } \\
\text { test }\end{array}$ & $\begin{array}{c}\text { Thrombin } \\
\text { test }\end{array}$ \\
\hline \multicolumn{4}{c}{$\begin{array}{c}\text { \% hemolysis } \\
\end{array}$} \\
3 & 62 & 48 & 64 \\
4 & 47 & 36 & 81 \\
5 & 49 & 15 & 57 \\
7 & 72 & 27 & 68 \\
8 & 28 & 17 & 45 \\
9 & 77 & 22 & 55 \\
10 & 19 & 13 & 84 \\
& & 10 & 22 \\
\end{tabular}

* $\mathrm{PNH}=$ paroxysmal nocturnal hemoglobinuria.

test for PNH has been discussed elsewhere (2). To date, significant hemolysis has been seen only with PNH erythrocytes. Over 200 other subjects, including normal individuals and patients with a variety of medical and hematologic diseases, have now been studied and have given negative results. A simplified screening test, the "sugar water" test, employing an aqueous solution of commercial granulated sugar and oxalated, citrated, or defibrinated whole blood, has proved equally specific for $\mathrm{PNH}$ (2).

Temperature. Significant hemolysis of $\mathrm{PNH}$ cells occurred in the sucrose system at room temperature $\left(23^{\circ}\right)$ and in general was only slightly less than at $37^{\circ}$ in the six patients studied. By contrast, hemolysis occurred in only one of these patients at $23^{\circ}$ in the acid hemolysis system. No hemolysis occurred with either test at $4^{\circ}$.

Ionic strength. The critical effect of ionic strength on sucrose hemolysis is shown in Figure 1. Maximal hemolysis was observed at ionic strength values of 0.017 and 0.026 . At 0.037 hemolysis was distinctly less. Above 0.049 no significant hemolysis occurred.

Serum requirements. No hemolysis occurred when saline-washed PNH erythrocytes were incubated in sucrose in the absence of serum. Maximal hemolysis occurred when the amount of serum in the reaction mixture was approximately $10 \%$ (Figure 2). The degree of hemolysis in the standard $5 \%$ serum reaction mixture was only slightly less. Although the per cent hemolysis in individual patients varied at each concentration of serum, the general configuration of the curve for each patient was similar to that of the mean curve. 


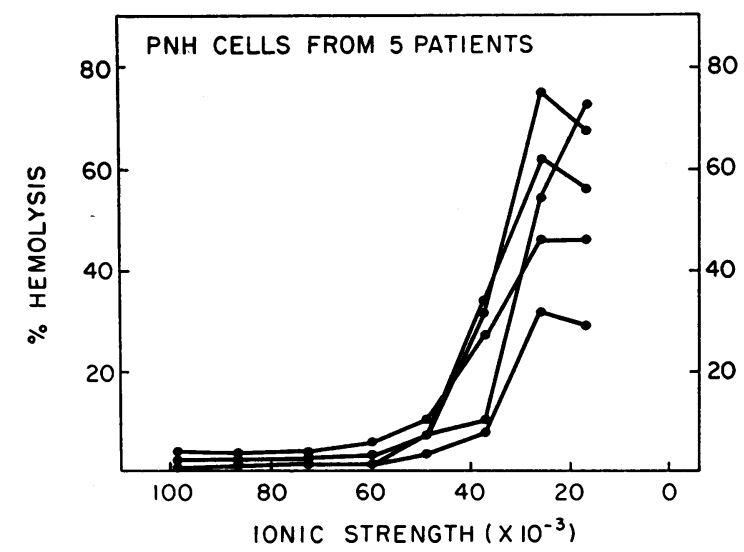

Fig. 1. SUCrose HeMOLYSIS: EFFECT OF IONIC STRENGTH. PNH = PAROXYSMAL NOCTURNAL HEMOGLOBINURIA.

Substitution of other saccharides and related alcohols for sucrose. The behavior of $\mathrm{PNH}$ and normal erythrocytes in low ionic strength solutions of other sugars was similar to that in sucrose solutions provided the solute chosen was one that does not readily enter human red cells. Thus when $0.27 \mathrm{M}$ buffered solutions of raffinose, mannitol, and sorbitol were substituted for sucrose, hemolysis was specific for PNH erythrocytes and occurred only in the presence of serum. With solutions of D-glucose and D-mannose, both of which enter red cells, hemolysis occurred with both normal and $\mathrm{PNH}$ cells even in the absence of serum.

$p H$. In the standard sucrose hemolysis test the $\mathrm{pH}$ of the serum-sucrose mixture before the addition of erythrocytes ranged from 6.5 to 6.7. Further adjustment of the $\mathrm{pH}$ of the serum-sucrose mixture over a wide range produced little change in $\mathrm{PNH}$ sucrose hemolysis (Figure 3).

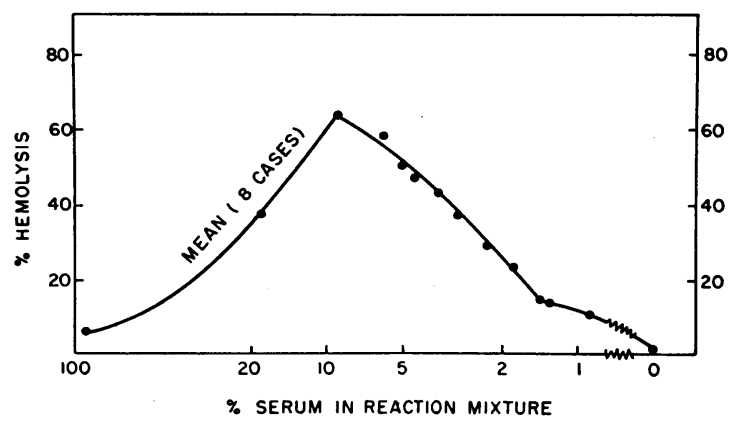

Fig. 2. SUCROSE HEMOLYSIS : EFFECT OF AMOUNT OF SERUM ON HEMOLYSIS OF PNH CELLS.

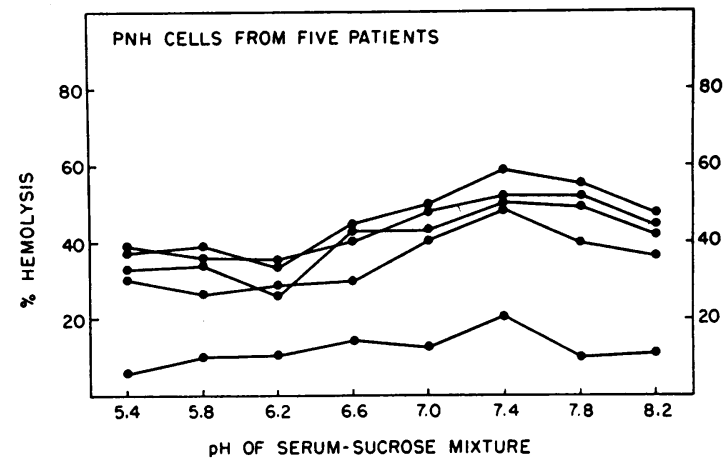

Fig. 3. SuCrose hemolysis : EFfECt OF PH.

Although somewhat greater hemolysis occurred at $\mathrm{pH} 7.4$, it was only slightly less at other $\mathrm{pH}$ levels. This is in marked contrast to the acid hemolysis reaction in which hemolysis may be appreciable only over a relatively narrow $\mathrm{pH}$ range (e.g., 6.2 to 6.8$)(7,14)$.

Role of complement in sucrose hemolysis. Table II demonstrates the effects of various types of serum treatment on the sucrose hemolysis of $\mathrm{PNH}$ erythrocytes. Serum that has been heated ( $56^{\circ} \mathrm{C}$ for 30 minutes) or serum treated to remove $C^{\prime} 1, C^{\prime} 2, C^{\prime} 3$, or $C^{\prime} 4$ did not support hemolysis. Serum treated to remove properdin did support hemolysis but to an appreciably diminished degree.

There was no significant loss of complement activity in serum diluted in isotonic sucrose solution and incubated at $4^{\circ}$ or $37^{\circ}$ for 30 minutes (Figure 4). When $\mathrm{PNH}$ or normal erythrocytes were added to the reaction mixture, there was a marked fall in serum complement activity, indi-

TABLE II

Sucrose hemolysis in heated serum and in serum treated to remove complement components or properdin

\begin{tabular}{lrrrrrr}
\hline & \multicolumn{6}{c}{ PNH patient no. } \\
\cline { 2 - 7 } \multicolumn{1}{c}{ Serum added } & $\mathbf{3}$ & $\mathbf{4}$ & $\mathbf{5}$ & $\mathbf{7}$ & $\mathbf{8}$ & $\mathbf{9}$ \\
\hline & & \% hemolysis \\
Untreated serum & 47 & 31 & 45 & 19 & 19 & 30 \\
Heated serum & 0 & 0 & 0 & 0 & 0 & 0 \\
R1 $\dagger$ & 0 & 0 & 0 & 0 & 0 & 0 \\
R2 & 0 & 0 & 0 & 0 & 0 & 0 \\
R3 & 0 & 0 & 0 & 0 & 0 & 0 \\
R4 & 0 & 0 & 0 & 0 & 0 & 0 \\
RP & 22 & 12 & 27 & 5 & 5 & 16 \\
\hline
\end{tabular}

* $56^{\circ} \mathrm{C}$ for 30 minutes.

$\dagger \mathrm{R} 1, \mathrm{R} 2, \mathrm{R} 3, \mathrm{R} 4=$ serum treated to remove $\mathrm{C}^{\prime} 1, \mathrm{C}^{\prime} 2$, $C^{\prime} 3, C^{\prime} 4$, respectively. $R P=$ serum treated to remove properdin. 


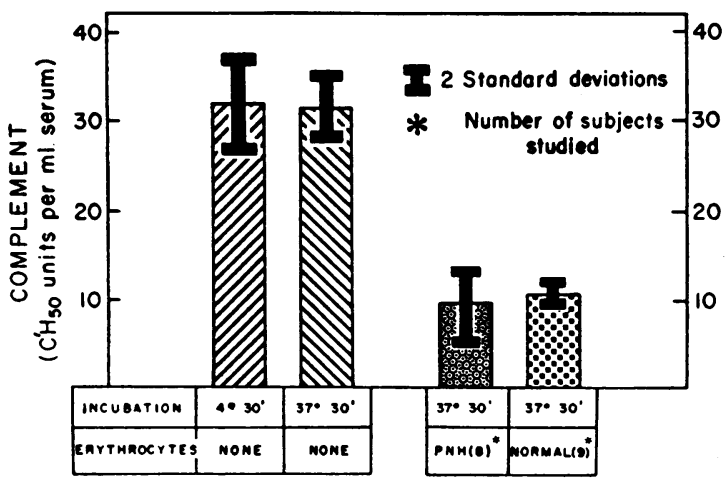

Fig. 4. Depletion OF COMPLEMENT ACtivity IN SERUMSUCROSE MIXTURES BY ERYTHROCYTES. $\mathrm{C}^{\prime} \mathrm{H}_{50} \mathrm{U}=50 \%$ hemolytic unit of complement.

cating that complement fixation had occurred. Moreover, serum-sucrose mixtures that had been exposed to normal red cells no longer produced significant hemolysis of $\mathrm{PNH}$ erythrocytes.

Normal erythrocytes as well as $\mathrm{PNH}$ erythrocytes surviving hemolysis in the serum-sucrose system were agglutinated by anti- $C^{\prime}$, anti- $\beta_{10^{-}}$ globulin, and anti- $\beta_{1 \mathrm{E}}$-globulin, providing further evidence for the participation of complement (Table III). Normal cells incubated with complement-fixing cold agglutinin antibodies showed similar reactions with these three antisera. In contrast, PNH cells surviving the classical acid hemolysis reaction, as reported previously, were agglutinated by anti- $\mathrm{C}^{\prime}$ and anti- $\beta_{10}$-globulin antisera but not by anti- $\beta_{1 \mathrm{E}}$-globulin (8). In none of these experiments did the cells react with anti- $\gamma \mathrm{G}$.

Anticoagulants. The addition of citrate and oxalate to the system produced no inhibition of $\mathrm{PNH}$ sucrose hemolysis even in concentrations up to 50 mmoles per $\mathrm{L}$ in serum or plasma. Such concentrations far exceed the average plasma

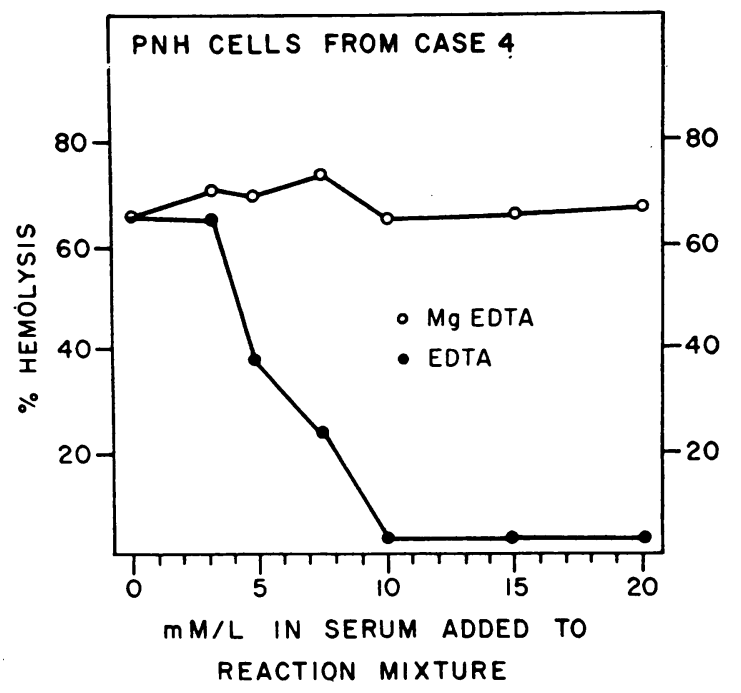

Fig. 5. SUCROSE HEMOLYSIS: COMPARISON OF EFFECTS OF EDTA AND MG-EDTA.

anticoagulant concentration for citrate and oxalate (approximately 15 mmoles per L). This permits substitution of oxalated and citrated plasma for serum in the sucrose hemolysis test, as we have reported elsewhere (2).

However, the concentration of EDTA $\left(\mathrm{Na}_{2} \mathrm{H}_{2}-\right.$ EDTA) was found to be critical ; serum containing 10 mmoles per $\mathrm{L}$ or more of this chelating agent failed to support $\mathrm{PNH}$ sucrose hemolysis. Since this is near the plasma concentration frequently present in whole blood anticoagulated with EDTA, such blood may not be suitable for sucrose hemolysis tests for PNH (2). On the other hand, $\mathrm{Mg}$-EDTA $\left(\mathrm{Na}_{2} \mathrm{Mg}-\mathrm{EDTA}\right)$, which binds calcium but not magnesium ions, was not inhibitory in serum concentrations of 20 mmoles per $\mathrm{L}$ (Figure 5) and in other experiments up to 50 mmoles per L.

Figure 6 shows the effect of heparin added

TABLE III

Identification of complement components on erythrocytes surviving sucrose hemolysis and other hemolytic reactions

\begin{tabular}{|c|c|c|c|c|c|c|}
\hline \multirow[b]{2}{*}{ Erythrocytes } & \multirow[b]{2}{*}{ Hemolytic reaction } & \multirow{2}{*}{$\begin{array}{l}\text { No. of } \\
\text { subjects } \\
\text { studied }\end{array}$} & \multicolumn{4}{|c|}{ Average antiglobulin agglutination score* } \\
\hline & & & Anti- $\gamma \mathrm{G}$ & Anti-C' & Anti- $\beta_{10}$ & Anti- $\beta_{1 E}$ \\
\hline $\begin{array}{l}\text { Normal } \\
\text { PNH } \\
\text { Normal }\end{array}$ & $\begin{array}{l}\text { Sucrose hemolysis } \\
\text { Sucrose hemolysis } \\
\text { Acid hemolysis } \\
\text { Cold agglutinint }\end{array}$ & $\begin{array}{r}10 \\
8 \\
6 \\
6\end{array}$ & $\begin{array}{l}0 \\
0 \\
0 \\
0\end{array}$ & $\begin{array}{l}3 \\
3 \\
2 \\
2\end{array}$ & $\begin{array}{l}2 \\
2 \\
1 \\
2\end{array}$ & $\begin{array}{l}2 \\
2 \\
0 \\
2\end{array}$ \\
\hline
\end{tabular}

* 4, maximal agglutination; 0 , no agglutination; and other numbers, intermediate scores.

$\uparrow$ Six separate cold agglutinin sera were incubated with blood group $O$ normal erythrocytes. 
to serum on the $\mathrm{PNH}$ sucrose hemolysis test. Ranges of heparin concentration that correspond to those in plasma obtained from routinely heparinized blood (e.g., 0.2 to $0.4 \mathrm{mg}$ per $\mathrm{ml}$ ) markedly inhibited the PNH sucrose hemolysis test.

Agglutination of erythrocytes. Rapid sedimentation and marked agglutination occurred with both PNH and normal cells in the sucrose system provided a small amount of either autologous or isologous serum was present. This took place at all temperatures tested $\left(37^{\circ}, 23^{\circ}\right.$, and $\left.4^{\circ}\right)$. Agglutination was most striking when the $\mathrm{pH}$ of the sucrose solution was less than 7.0 and persisted even when heated serum or plasma treated with $500 \mathrm{mg}$ per $\mathrm{ml}$ of $\mathrm{BaSO}_{4}$ was used in the reaction mixture. Thus agglutination persisted even with serum or plasma that no longer supported hemolysis of $\mathrm{PNH}$ erythrocytes. At $37^{\circ}$ and $23^{\circ}$ the agglutination of $\mathrm{PNH}$ erythrocytes diminished within 2 to 5 minutes as hemolysis began. At $4^{\circ}$ agglutination of $\mathrm{PNH}$ cells persisted and no hemolysis occurred. Normal cells remained agglutinated at all temperatures.

The agglutinates formed were soft in character. The red cells were not bound tightly together, and vigorous shaking readily dispersed them. The individual cells in or separated from the agglutinates appeared as normal biconcave discs and showed no crenation when examined under a bright light or phase microscope immediately after mixing or after 30 minutes' incubation in the serum-sucrose mixture. Washing the cells from the sucrose he-

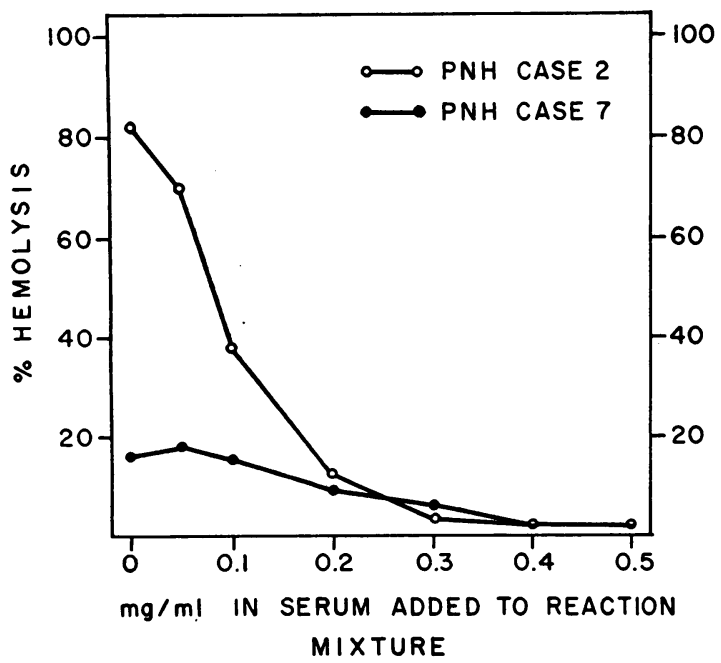

Fig. 6. SUCROSE HEMOLYSIS : EFFECT OF HEPARIN.
TABLE IV

Effect of $\mathrm{BaSO}_{4}$ adsorption on sucrose hemolysis*

\begin{tabular}{|c|c|c|c|}
\hline $\begin{array}{c}\mathrm{BaSO}_{4} \\
\text { adsorption }\end{array}$ & $\begin{array}{c}\text { Prothrom- } \\
\text { bin time }\end{array}$ & $\begin{array}{c}\text { Sucrose } \\
\text { hemolysis }\end{array}$ & Complement \\
\hline$\underset{\text { plasma }}{m g / m l}$ & seconds & $\%$ & $\begin{array}{l}C^{\prime} H_{s 0} U \ddagger / \\
\text { ml plasma }\end{array}$ \\
\hline $\begin{array}{r}0 \\
100 \\
250 \\
500\end{array}$ & $\begin{array}{l}15 \\
\infty \S \\
\infty \\
\infty\end{array}$ & $\begin{array}{r}59(33-94) \\
54(24-86) \\
31(2-66) \\
2(2-3)\end{array}$ & $\begin{array}{r}30(28-32) \\
29(26-30) \\
19(8-26) \\
5(2-7)\end{array}$ \\
\hline
\end{tabular}

* Results represent average values for four normal plasmas with ranges in parentheses. Each plasma tested in sucrose hemolysis against cells of two $\mathrm{PNH}$ patients.

† Oxalated plasma.

$\mp \mathrm{C}^{\prime} \mathrm{H}_{50} \mathrm{U}=50 \%$ hemolytic unit of complement.

$\S \infty=$ No clot in 24 hours.

molysis system with $0.85 \%$ saline completely reversed the agglutination.

Role of thrombin. There was no evidence that any evolution of thrombin during the incubation period was necessary for PNH sucrose hemolysis. Oxalated or citrated plasma functioned effectively as a substitute for serum in sucrose hemolysis, and there was no visible sign of clotting during the reaction. In addition, treatment of oxalated plasma with $100 \mathrm{mg}$ of $\mathrm{BaSO}_{4}$ per $\mathrm{ml}$ completely removed prothrombin, the precursor of thrombin, from plasma without significantly altering sucrose hemolysis or complement activity (Table IV). With larger amounts of $\mathrm{BaSO}_{4}$, however, these activities as well as prothrombin activity were affected. With $500 \mathrm{mg}$ of $\mathrm{BaSO}_{4}$ per $\mathrm{ml}$, complement and sucrose hemolysis activity were almost completely removed from the plasma. At $250 \mathrm{mg}$ the results varied with individual plasmas.

Although commercial bovine thrombin enhances $\mathrm{PNH}$ acid hemolysis, no such effect was noted in the sucrose hemolysis reaction (Table V). In fact the addition of increasing amounts of thrombin to the sucrose system resulted in a progressive decrease in hemolysis. In contrast, acid hemolysis was significantly increased by thrombin in concentrations up to $200 \mathrm{U}$ per $\mathrm{ml}$ of serum. At higher concentrations of thrombin, however, inhibition of acid hemolysis also occurred.

Trypsinized erythrocytes. Normal erythrocytes, treated with a variety of proteolytic enzymes, may acquire some characteristics resembling $\mathrm{PNH}$ cells, notably a positive acid hemolysis test (13). Trypsin has been commonly used for this purpose. However, trypsinized normal human eryth- 
TABLE V

Effect of thrombin on $P N H$ hemolysis

\begin{tabular}{lllllllll}
\hline \hline & \multicolumn{6}{c}{ Bovine thrombin $(U / m l$ serum $)$} \\
\cline { 2 - 8 } & 0 & 25 & 50 & 100 & 200 & 500 & 1,000 \\
\hline Sucrose hemolysis, \%* & 60 & 57 & 54 & 44 & 34 & 36 & 27 \\
Acid hemolysis, \%* & 25 & 69 & 64 & 43 & 31 & 7 & 13 \\
\hline
\end{tabular}

* Mean of per cent hemolysis values with cells of four PNH patients.

rocytes did not hemolyze or even agglutinate in the serum-sucrose system although definite acid hemolysis (range 20 to $90 \%$ ) did occur with these cells, as reported by others (13).

\section{Discussion}

These studies demonstrate that human serum diluted in isotonic, low ionic strength sucrose solution is capable of hemolyzing $\mathrm{PNH}$ erythrocytes. Normal cells or cells from patients with disorders other than $\mathrm{PNH}$ agglutinated but did not undergo hemolysis. The most important determining factor in the sucrose hemolysis system appeared to be the reduction in ionic strength, since raising ionic strength by increasing the proportion of serum or saline progressively diminished the hemolysis of $\mathrm{PNH}$ erythrocytes. Certain sugars and related compounds (e.g., raffinose, mannitol, and sorbitol) that do not readily enter the red cell provided an equally effective isotonic, low ionic strength medium and could be substituted for sucrose in this reaction.

There are several important differences between sucrose hemolysis and acid hemolysis of $\mathrm{PNH}$ cells. Acid hemolysis occurs over a relatively narrow range of $\mathrm{pH}(7,14)$, does not usually take place at room temperature, is inhibited by both citrate and oxalate (15), and requires at least a $25 \%$ serum concentration (16). Sucrose hemolysis, on the other hand, was insensitive to large changes in $\mathrm{pH}$, occurred regularly at room temperature, was not inhibited by citrate or oxalate, and required much less serum. Furthermore, concentrations of commercial thrombin that enhanced acid hemolysis did not augment sucrose hemolysis.

In some respects the sucrose hemolysis system resembles classical erythrocyte-antibody-complement $\left(\mathrm{EAC}^{\prime}\right)$ hemolytic systems. There was marked reduction in serum complement activity during the sucrose hemolysis reaction. In addition, both normal and $\mathrm{PNH}$ erythrocytes incu- bated in this system became coated with $\beta_{1 \mathrm{c}^{-}}$and $\beta_{1 \mathrm{E}}$-globulins, similar to normal erythrocytes incubated with the complement-fixing cold agglutinin antibody (17). In contrast, $\mathrm{PNH}$ erythrocytes surviving acid hemolysis are coated with $\beta_{10^{-}}$ globulin but not with $\beta_{1 \mathrm{E}}$-globulin (8). This latter finding is consistent with the thesis that the conditions of the acid hemolysis reaction serve to generate late acting complement components in serum, which then attach directly to the abnormal $\mathrm{PNH}$ erythrocyte to bring about acid hemolysis without the mediation of antibody $(18,19)$.

The marked agglutination of cells tested in the serum-sucrose system is of interest in comparing sucrose hemolysis with classical EAC' hemolysis. Clearly the agglutination was not an effect of the low ionic strength alone since it did not occur in the absence of serum. It is possible that a serum protein is altered in configuration in the low ionic strength medium so as to acquire "antibody-like" characteristics. The coating of erythrocytes with $\beta_{1 E^{-}}$and $\beta_{1 C^{-}}$-globulins in this system is consistent with this interpretation. The observation that agglutination was more striking when the $\mathrm{pH}$ of the sucrose solution was less than 7.0 is similar to the finding that the agglutinating effect of known antibodies is most marked below pH 7.0 (20).

The agglutinating phenomenon in the serumsucrose system could be separated from the hemolysis of $\mathrm{PNH}$ erythrocytes. When heated serum or oxalated plasma treated with $\mathrm{BaSO}_{4}$ ( $500 \mathrm{mg}$ per $\mathrm{ml}$ ) was used in the sucrose system, PNH erythrocytes failed to hemolyze but agglutination persisted. This, however, does not eliminate the agglutinating factor as a possible prerequisite for $\mathrm{PNH}$ sucrose hemolysis. Further attempts to isolate and characterize the agglutinating factor are in progress.

The findings of Harshman and Najjar (6) are of interest in this regard. In their experiments normal human erythrocytes were separated from serum or plasma, washed with buffered $0.27 \mathrm{M}$ sucrose solution, and then suspended in $0.15 \mathrm{M}$ sodium chloride. After centrifugation the saline supernatant was analyzed and found to contain $\gamma$-globulin with the following blood group isohemagglutinin activities: anti-B was recovered from A cells, anti-A from B cells, and anti-A plus anti-B from $O$ cells. Antiglobulin tests were not performed on the cells. We initially considered 
that these isohemagglutinins might have antibodylike function in the sucrose hemolysis system and thus be a necessary requirement for the observed reactions. This does not appear to be the case, however, since $A B$ serum, lacking these isohemagglutinins, behaved entirely the same as blood group specific serum with respect to the agglutination, complement coating, and $\mathrm{PNH}$ hemolysis observed in the sucrose system.

Reduction in ionic strength has been previously shown to enhance the efficiency of the classical complement system $(21,22)$. Such studies demonstrated that hemolysis of sheep erythrocytes by rabbit antibody and guinea pig complement is maximal at ionic strengths of 0.05 to 0.08 , a much higher range than that producing maximal sucrose hemolysis of $\mathrm{PNH}$ erythrocytes. In addition, Mollison and Polley have reported that $\beta_{10^{-}}$and $\beta_{1 \mathrm{E}}$-globulins coat normal cells incubated with serum previously dialyzed against sucrose or diluted in sucrose (23), and that $\gamma$-globulin also coats normal cells incubated in sucrose-dialyzed serum. In our studies, $\gamma$-globulin was not detected on either normal or PNH erythrocytes subjected to the sucrose hemolysis reaction.

More recently Yachnin has shown that acid hemolysis of $\mathrm{PNH}$ erythrocytes can be enhanced by the use of sucrose-dialyzed serum (24). It was suggested that the low ionic strength favored reactions involved in the attachment of late acting complement components to $\mathrm{PNH}$ cells in the acid hemolysis reaction. An alternative explanation would be that the enhancement is due to mechanisms relating to the sucrose hemolysis reaction in which early acting ( $\beta_{1 \mathrm{E}}$-globulin) as well as late acting ( $\beta_{1 \mathrm{C}}$-globulin) complement components are attached to the $\mathrm{PNH}$ erythrocyte.

The observation that neither citrate nor oxalate blocked sucrose hemolysis probably is due to the relatively great dissociation of both calcium and magnesium from these ligands. This dissociation may be even greater in solutions of low ionic strength, since Walser has reported that sodium ion suppresses the ionization of calcium and magnesium citrate (25). On the other hand, $\mathrm{Na}_{2} \mathrm{H}_{2-}$ EDTA, which binds both magnesium and calcium ions much more avidly, ${ }^{6}$ entirely prevented su-

\footnotetext{
${ }^{6} \mathrm{pK} \mathrm{Ca}$ citrate, 3.22 ; $\mathrm{pK} \mathrm{Mg}$ citrate, $3.20 ; \mathrm{pK} \mathrm{Ca}-$ EDTA, 10.59; pK Mg-EDTA, 8.69 (26).
}

crose hemolysis of $\mathrm{PNH}$ erythrocytes when its concentration exceeded the combined concentrations of calcium and magnesium ions, as is likely to occur in routine anticoagulant concentrations. When the concentration of $\mathrm{Na}_{2} \mathrm{H}_{2}-\mathrm{EDTA}$ is slightly less than the combined concentrations of both cations, ionized magnesium and calcium are present in concentrations adequate to support PNH hemolysis. The fact that $\mathrm{Na}_{2} \mathrm{Mg}$-EDTA does not inhibit sucrose hemolysis of PNH cells, irrespective of its concentration (e.g., up to 50 mmoles per L), demonstrates that the critical ion is magnesium and not calcium.

The findings reported in this study have practical as well as theoretical implications. To date, significant hemolysis in the sucrose hemolysis system has been specific for PNH. With commercial sugar as the source of sucrose, a simplified and highly specific screening test for $\mathrm{PNH}$ can be carried out at room temperature with fresh unbuffered sugar water and oxalated, citrated, or defibrinated whole blood (2). The requirement for small amounts of serum makes long-term studies of the hemolytic defect of $\mathrm{PNH}$ erythrocytes more practical using, for example, group $\mathrm{AB}$ reference serum frozen in small portions at $-70^{\circ} \mathrm{C}$. Moreover, the sucrose system provides an easy and rapid method to prepare complement-sensitized cells for the serologic laboratory.

\section{Acknowledgments}

We wish to express appreciation to Mrs. Anita B. Arnold, Mrs. Mary D. Birdsong, Mr. John J. Coleman, and Mr. John F. Nelson for technical assistance in these studies.

\section{References}

1. Hartmann, R. C., D. E. Jenkins, Jr., and A. L. Kerns. Complement fixation and hemolysis by normal serum in sucrose solution of low ionic strength. Clin. Res. 1966, 14, 90.

2. Hartmann, R. C., and D. E. Jenkins, Jr. The "sugar water" test for paroxysmal nocturnal hemoglobinuria. New Engl. J. Med. 1966, 275, 155.

3. Hartmann, R. C., and J. V. Auditore. Paroxysmal nocturnal hemoglobinuria. I. Clinical studies. Amer. J. Med. 1959, 27, 389.

4. Hartmann, R. C., D. E. Jenkins, Jr., L. C. McKee, and R. M. Heyssel. Paroxysmal nocturnal hemoglobinuria: clinical and laboratory studies relating to iron metabolism and therapy with androgen and iron. Medicine (Baltimore) 1966, 45, 331. 
5. Kabat, E. A., and M. M. Mayer. Experimental Immunochemistry. Springfield, Ill., Charles C Thomas, 1961, pp. 133-240.

6. Harshman, S., and V. A. Najjar. The binding of autologous $\boldsymbol{\gamma}$-glcbulin with isohemagglutinin activity to human red blood cells. Biochem. biophys. Res. Commun. 1963, 11, 411.

7. Auditore, J. V., R. C. Hartmann, and J. M. Flexner. Role of $\mathrm{pH}$ and thrombin in the $\mathrm{PNH}$ hemolytic system. J. appl. Physiol. 1960, 15, 25.

8. Jenkins, D. E., Jr., W. N. Christenson, and R. L. Engle, Jr. Detection of complement components on unlysed erythrocytes from acid hemolysis and thrombin test reactions in paroxysmal nocturnal hemoglobinuria. J. clin. Invest. 1966, 45, 796.

9. Pillemer, L., L. Blum, I. H. Lepow, L. Wurz, and E. W. Todd. The properdin system and immunity. III. The zymosan assay of properdin. J. exp. Med. 1956, 103, 1.

10. Scheidegger, J. J. Une micro-methóde de l'immunoélectrophorèse. Int. Arch. Allergy 1955, 7, 103.

11. Müller-Eberhard, H. J., U. Nilsson, and T. Aronsson. Isolation and characterization of two $\beta_{1}$-glycoproteins of human serum. J. exp. Med. 1960, 111, 201.

12. Müller-Eberhard, H. J., and C. E. Biro. Isolation and description of the fourth component of human complement. J. exp. Med. 1963, 118, 447.

13. Yachnin, S., M. T. Laforet, and F. H. Gardner. $\mathrm{pH}$ dependent hemolytic systems. I. Their relationship to paroxysmal nocturnal hemoglobinuria. Blood 1961, 17, 83.

14. Dacie, J. V. The Haemolytic Anaemias-Congenital and Acquired. London, J. and A. Churchill, 1954, pp. 431-32.

15. Clapp, M. P., M. J. Williams, and J. L. Mendel. Observations on the hemolytic mechanism of paroxysmal nocturnal hemoglobinuria. Demonstration of the activity of at least two serum factors in PNH hemolysis. Blood 1952, 7, 1117.
16. Yachnin, S., and J. Ruthenberg. Role of calcium in complement dependent hemolysis. Proc. Soc. exp. Biol. (N. Y.) 1964, 117, 179.

17. Harboe, $M$. Interactions between ${ }^{121} \mathrm{I}$ trace-labelled cold agglutinin, complement and red cells. Brit. J. Haemat. 1964, 10, 339.

18. Yachnin, S., and J. M. Ruthenberg. The initiation and enhancement of human red cell lysis by activators of the first component of complement and by first component esterase; studies using normal red cells and red cells from patients with paroxysmal nocturnal hemoglobinuria. J. clin. Invest. 1965, 44, 518.

19. Yachnin, S. The hemolysis of red cells from patients with paroxysmal nocturnal hemoglobinuria by partially purified subcomponents of the third complement component. J. clin. Invest. 1965, 44, 1534.

20. Pollack, W. Some physicochemical aspects of hemagglutination. Ann. N. Y. Acad. Sci. 1965, 127, 892.

21. Wardlaw, A. C., and H. G. Walker. The effect of ionic strength on the haemolytic activity of complement. Immunology 1963, 6, 291.

22. Rapp, H. J., and T. Borsos. Effects of low ionic strength on immune hemolysis. J. Immunol. 1963, 91, 826.

23. Mollison, P. L., and M. J. Polley. Uptake of $\gamma$-globulin and complement by red cells exposed to serum at low ionic strength. Nature (Lond.) 1964, 203, 535 .

24. Yachnin, S. Effect of ionic strength upon hemolysis of paroxysmal nocturnal hemoglobinuria erythrocytes. Proc. Soc. exp. Biol. (N. Y.) 1965, 120, 715.

25. Walser, M. Ion association. V. Dissociation constants for complexes of citrate with sodium, potassium, calcium, and magnesium ions. J. phys. Chem. 1961, 65, 159.

26. Des Prez, R. M., and R. E. Bryant. Effects of bacterial endotoxin on rabbit platelets. IV. The divalent ion requirements of endotoxin-induced and immunologically induced platelet injury. J. exp. Med. 1966, 124, 971. 